\title{
Physical Characteristics of Brazilian Wheat and their Utilization as an Indication of Flour Extraction
}

\author{
Rogério Germani* and José Luiz Viana de Carvalho. \\ EMBRAPA Centro Nacional de Pesquisa de Tecnologia Agroindustrial de Alimentos - Av. das Américas, 29501, \\ Guaratiba 23020-470 - Rio de Janeiro, RJ, Brazil.
}

\begin{abstract}
An extensive work to determine the test weight (TW), the thousand kernel weight (TKW) and the hardness (HD) of Brazilian wheat, was undertaken for the crop years from 1990 to 1994, with the objetive of drawing the Brazilian wheat physical characteristics and their relationship with flour extraction (FE). The results showed a median TW of $78.2 \mathrm{~kg} / \mathrm{hl}$, a TKW of $34.2 \mathrm{~g}$ and the HD was graded as hard. The values varied accordingly with the crop year, the local and year vs. local. Among the locals the wheat from the MS/DF/MG/GO States showed the best results. Correlation coefficients between FE and each of the parameters, TW, TKW and HD were low but significant $(P<5.0 \%)$ and, therefore, should not be used as a direct relationship but only as an indicator of FE. Segregation of TW, TKW and HD by specific ranges did not improve the correlation coefficient values.
\end{abstract}

Key words: wheat; flour extraction; hectoliter weight, thousand kernel weight; hardness.

\section{INTRODUCTION}

The measurement of the kernel apparent density (mass per volume unit) has been used as a parameter of wheat quality for commercial purpose in several countries (Zeleny, 1978). In Brazil, the kernel test weight (TW), measured as kilogram per hectoliter, was the only commercial quality parameter utilysed until 1994. Although this parameter reflects very reasonably the grain sanity and its degree of development, it is also used as an indicator of the milling flour extraction (FE). Kremer (1993) found a high correlation between TW and FE while Johnson \& Harris (1995) and Schuler et al (1995) did not find a significant correlation coefficient. Other parameters used as flour yield indicators are thousand kernel weight (TKW) (El-Shirbeeny \& Allam, 1987) and kernel hardness (Baker \& Dick, 1975). These works showed distinct results, however, they were conducted in countries were the conditions are very much different from Brazil and, therefore, can show different results. The objetive of this work was to evaluate the relationship between the milling flour extraction and the kernel test weight, the thousand kernel weight and the kernel hardness, from material grown in Brazil, as well as to relate the technological characteristics of Brazilian wheat to these parameters.

\section{MATERIALS AND METHODS}

The wheat samples were obtained from the following experimental fields: FECOTRIGOFederação da Cooperativas de Trigo de Cruz AltaRS; EMBRAPA-CNPT (Centro Nacional de Pesquisa de Trigo), Passo Fundo-RS; Empresa de Pesquisa Agropecuária (EPAGRI), Santa Catarina state; Instituto Agronômico do Paraná (IAPAR). Londrina-PR; Organização das Cooperativas do Paraná (OCEPAR), Cascavel-PR; EMBRAPACNPSo (Centro Nacional de Pesquisa de Soja), Londrina-PR; EMBRAPA-CPAO (Centro de Pesquisa Agropecuária do Oeste), Dourados-MS; Instituto Agronômico de Campinas (IAC), SP and EMBRAPA-CPAC (Centro de Pesquisa Agropecuária do Cerrado), Brasília-DF. For the purpose of this work, the samples from MS, DF, MG and GO were considered together in one

* Author for correspondence 
group, since the recommended cultivars and the climatic conditions are similar. All the samples were conditioned to $15.0 \%$ moisture for $16-24 \mathrm{hs}$ prior to milling in a Brabender Qadrumat Senior mill, as described by Germani et al (1997). The moisture determination was done according to the method 44-15A from AACC (1983) and the ash content to the method 2.055 from AOAC (1984). Test weight was determined according to the equipment manufacturer (Dalle Molle) instructions, as described by Germani et al (1997) and, the thousand kernel weight, as described by SHUEY \& GILLES (1972). The kernel hardness was tested using the Brabender micro hardness tester, as described by Kosmolak (1978), which measures the time required to grind $4 \mathrm{~g}$ of wheat (for times below 32sec, the kernel is defined as hard, between 33 and $45 \mathrm{sec}$, as semi-hard, between 46 and $63 \mathrm{sec}$, as semi-soft, and above $63 \mathrm{sec}$, as soft).

\section{RESULTS AND DISCUSSION}

For this study 3250 samples of wheat from 1990, 1991, 1992, 1993 and 1994 crop year were used. Cumulative distribution of FE, TW, TKW and HD values are shown in Table 1. It could be seen that FE varied from 40.4 to $78.9 \%$, with a median value of $64.5 \%$. On the other hand, the TW showed the least variation, and its median was $78.2 \mathrm{~kg} / \mathrm{hl}$. For the TKW, the median value was $34.2 \mathrm{~g}$. The higher variation was observed with $\mathrm{HD}$, which varied from 15 to $999 \mathrm{sec}$, with a median value of $45 \mathrm{sec}$. By the Kosmolak (1978) hardness scale, this median hardness value classified the wheat as hard. FE, TW and TKW distribution are illustrated in Figures 1,2 and 3, respectively.

Table 1. Empirical cumulative distribution values regarding flour extration (FE), test weight (TW), thousand kernel weight (TKW) and hardness (HD).

\begin{tabular}{llllllllllr}
\hline & Min. & $5 \%$ & $10 \%$ & $25 \%$ & $50 \%$ & $75 \%$ & $90 \%$ & $95 \%$ & Máx. & CV\% \\
\hline FE & 40.4 & 53.6 & 56.5 & 60.5 & 64.5 & 68.4 & 71.5 & 73.4 & 78.6 & 9.2 \\
TW & 60.2 & 69.8 & 72.1 & 75.2 & 78.2 & 80.4 & 82.1 & 83.1 & 84.9 & 5.3 \\
TKW & 17.3 & 25.2 & 27.0 & 30.3 & 34.2 & 38.2 & 41.7 & 44.0 & 56.0 & 16.9 \\
HD* & $15(\mathrm{VH})$ & $17(\mathrm{VH})$ & $18(\mathrm{VH})$ & $22(\mathrm{VH})$ & $41(\mathrm{H})$ & $72(\mathrm{SS})$ & $125(\mathrm{~S})$ & $211(\mathrm{~S})$ & $999(\mathrm{~S})$ & 132.9 \\
\hline
\end{tabular}

*VH=very hard. $\mathrm{H}=$ hard. $\mathrm{SS}=$ semi-soft. $\mathrm{S}=$ soft.

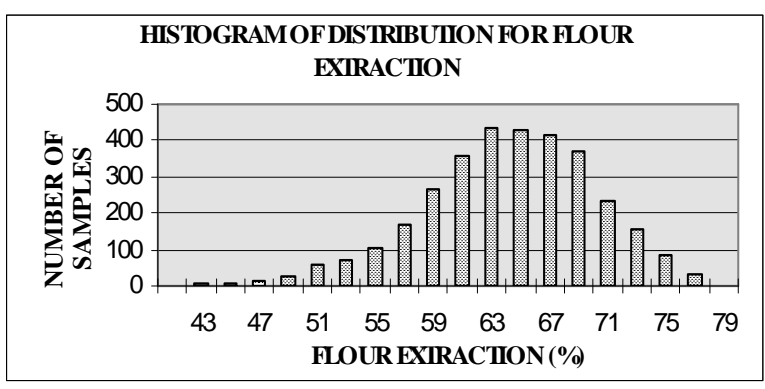

Figure 1. Flour extration values distribution histogram.

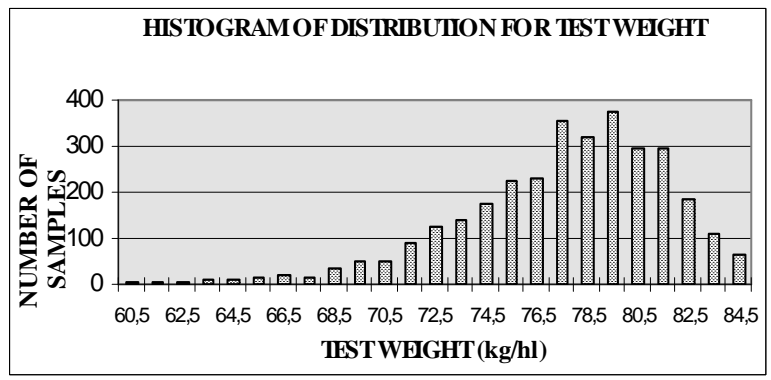

Figure 2. Test weight values distribution histogram.

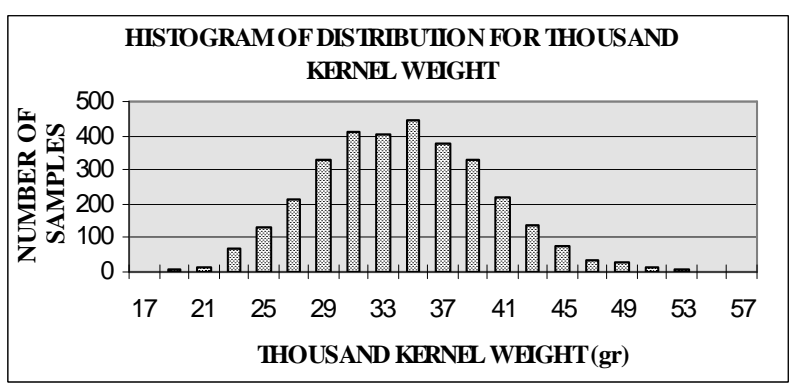

Figure 3. Thousand kernel weight values distribution histogram

Evaluating the local and crop year influence, it can be observed that there are significance differences among the samples cropped in the differents states in different years as well as between the inter relation year/state for all parameters studied (Table 2).

A simple correlation analysis among FE, TW, TKW, HD and flour ash content are shown in Table 3. It could be observed that FE has a small 
but positive correlation coefficient with TW and TKW, and a negative correlation with HD, showing that these parameters can not be straightly related, but only used as an indicator of FE. The low correlation found between FE and flour ash indicated that the FE values variation was not caused by deficiency in the milling process. Schuler et al (1995) and Johnson \& Harris (1995) did not find a significant correlation between FE and TW or TKW.

Table 2. Analysis of variance for the wheat kernel characteristics

\begin{tabular}{|c|c|c|c|c|c|}
\hline \multirow[b]{2}{*}{ Source of variation } & \multirow[b]{2}{*}{ D.F. } & \multicolumn{4}{|c|}{ Chi square } \\
\hline & & $\begin{array}{c}\text { Flour } \\
\text { Extration } \\
\end{array}$ & $\begin{array}{c}\text { Test } \\
\text { Weight }\end{array}$ & $\begin{array}{c}\text { Thousand } \\
\text { Kernel Weight }\end{array}$ & Hardness \\
\hline Year & 4 & $2115.2 *$ & $645.2 *$ & $976.6^{*}$ & $4306.7 *$ \\
\hline State & 4 & $560.9^{*}$ & $109.7 *$ & $982.5^{*}$ & $14160.7 *$ \\
\hline Year/state & 13 & $313.2 *$ & $184.3^{*}$ & $299.7 *$ & $5258.9 *$ \\
\hline Residous & 25 & 4.9 & 3.4 & 5.1 & 20.3 \\
\hline C.V. $(\%)$ & & 7.69 & 4.4 & 149 & 41.4 \\
\hline
\end{tabular}

* Significance at $\mathrm{P}<5.0 \%$.

To verify if the relations between $\mathrm{FE}$ and TW were influenced by the apparent kernel density, the coefficient of determination between these two parameters in several TW ranges was calculated as shown in Table 4. It was observed that the correlation coefficients were still low and the higher ones were for the range of $\mathrm{TW}<70$ and of $\mathrm{TW}<75 \mathrm{~kg} / \mathrm{hl}$, which were responsible for 19 and $12 \%$ of FE variation, respectively.

Table 3. Correlation coefficient among several parameters.

\begin{tabular}{|c|c|c|c|c|}
\hline & \multicolumn{3}{|c|}{ Thousand } & \multirow[b]{2}{*}{ Flour Ash } \\
\hline & Test Weght & Kernel Weight & Hardness & \\
\hline Flour Extraction & $0.317 *$ & $0.246^{*}$ & $-0.253 * *$ & $0.162 *$ \\
\hline Test Weight & & $0.432 *$ & $-0.015^{\mathrm{ns}}$ & $-0.347 *$ \\
\hline Thousand Kernel Weight & & & $0.025^{\mathrm{ns}}$ & $-0.175^{*}$ \\
\hline Hardness & & & & $-0.010^{\mathrm{ns}}$ \\
\hline
\end{tabular}

- Significance at $\mathrm{P}<5.0 \%$. $\mathrm{ns}=$ non significant. 
Table 4. Coefficient of etermination $\left(\mathrm{R}^{2}\right)$ from the relation between flour extraction (FA) and test weight

\begin{tabular}{llc} 
(TW) & & \\
\hline TW range & $\mathrm{R}^{2}$ & Number of samples \\
\hline TW $<70$ & $0.188^{*}$ & 168 \\
$70 \leq \mathrm{TW}<75$ & $0.040^{*}$ & 621 \\
$75 \leq \mathrm{TW}<80$ & $0.010^{*}$ & 1462 \\
$\mathrm{TW} \geq 80$ & $0.009^{*}$ & 950 \\
$\mathrm{TW}<75$ & $0.120^{*}$ & 789 \\
$\mathrm{TW}<80$ & $0.064^{*}$ & 2252 \\
$70 \leq \mathrm{TW}<80$ & $0.021^{*}$ & 2086 \\
TW $\geq 70$ & $0.063^{*}$ & 3035 \\
TW $\geq 75$ & $0.050^{*}$ & 2456 \\
\hline GLOBAL & $0.102^{*}$ & 3202
\end{tabular}

* Significance at $\mathrm{P}<5.0 \%$.

Similar segregation was performed with TKW (Table 5). In this case, any TKW value range gave expressive correlation coefficient with FE, since none of the ranges accounted for more than $6.0 \%$ of $\mathrm{FE}$ variation.

If the coefficient of determination was calculated between $\mathrm{FE}$ and $\mathrm{HD}$, and the hardness values segregated by ranges (Table 6), it was observed that there was a great improvement in the $\mathrm{R}^{2}$ value which increased from $6.4 \%$ to $22.0 \%$. Although the values of $\mathrm{R}^{2}$, for the range of $\mathrm{HD} \leq 45$ and $\mathrm{HD} \leq 63$, were similar to $\mathrm{HD} \leq 32$, their contribution were irrelevant since the $R^{2}$ values between these ranges were not significant.

The correlation between TW and TKW with FE was also calculated within hardness ranges (Table 7). It was observed that the influence of TW on FE was improved in the range of $\mathrm{HD} \leq 32 \mathrm{sec}$, the range where it was classified as very hard. On the other hand, there was no expressive change for TKW.
The material segregation by range of values, within each parameter, did not show any expressive improvement on the relationship with FE.

Table 5. Coefficient of determination $\left(\mathrm{R}^{2}\right)$ for the relation between flour extraction (FE) and thousand kernel weight (TKW).

\begin{tabular}{lcc}
\hline Range of TKW values & $\mathrm{R}^{2}$ & $\begin{array}{c}\text { Number of } \\
\text { Samples }\end{array}$ \\
\hline TKW $<30$ & $0.059^{*}$ & 764 \\
$30 \leq \mathrm{TKW}<35$ & $0.010^{*}$ & 1049 \\
$35 \leq \mathrm{TKW}<40$ & $0.002^{\text {ns }}$ & 922 \\
TKW $\geq 40$ & $0.008^{*}$ & 505 \\
TKW $<35$ & $0.054^{*}$ & 1813 \\
TKW $<40$ & $0.053^{*}$ & 2735 \\
$30 \leq \mathrm{TKW}<40$ & $0.012^{*}$ & 1971 \\
TKW $\geq 30$ & $0.020^{*}$ & 2477 \\
TKW $\geq 35$ & $0.010^{*}$ & 1427 \\
\hline GLOBAL & $0.060^{*}$ & 3240 \\
\hline
\end{tabular}

* Significance at $\mathrm{P}<5.0 \%$; ${ }^{\mathrm{ns}}$ non significant.

Table 6. Coefficient of determination $\left(\mathrm{R}^{2}\right)$ for the relation between flour extraction (FE) and hardness (HD).

\begin{tabular}{llc}
\hline $\begin{array}{l}\text { Hardness } \\
\text { range } \\
(\mathrm{sec})\end{array}$ & $\mathrm{R}^{2}$ & Number of samples \\
\hline $\mathrm{HD} \leq 32$ & $0.215^{*}$ & 1298 \\
$32<\mathrm{HD} \leq 45$ & $0.006^{\mathrm{ns}}$ & 465 \\
$45<\mathrm{HD} \leq 63$ & $0.004^{\mathrm{ns}}$ & 491 \\
$\mathrm{HD}>63$ & $0.0002^{\mathrm{ns}}$ & 953 \\
$\mathrm{HD} \leq 45$ & $0.222^{*}$ & 1763 \\
$\mathrm{HD} \leq 63$ & $0.239^{*}$ & 2254 \\
$32<\mathrm{HD} \leq 63$ & $0.022^{*}$ & 956 \\
$\mathrm{HD}>45$ & $0.0008^{\mathrm{ns}}$ & 1478 \\
$\mathrm{HD}>32$ & $0.006^{*}$ & 1949 \\
\hline GLOBAL & $0.064^{*}$ & 3207 \\
\hline * Significance at $\mathrm{P}<5.0 \%{ }^{\text {ns }}$ non significant.
\end{tabular}

Table 7. Variation of the coefficient of determination $\left(\mathrm{R}^{2}\right)$ for the relation between flour extraction (FE) and test weight (TW), and between FE and thousand kernel weight (TKW), within the hardness ranges.

\begin{tabular}{|c|c|c|c|c|}
\hline \multirow[t]{2}{*}{ Range of hardness (sec) } & \multicolumn{2}{|c|}{$(\mathrm{FE} \times \mathrm{TW})$} & \multicolumn{2}{|c|}{$(\mathrm{FE} \times \mathrm{TKW})$} \\
\hline & $\mathrm{R}^{2}$ & $\begin{array}{c}\text { Number of } \\
\text { samples }\end{array}$ & $\mathrm{R}^{2}$ & $\begin{array}{c}\text { Number of } \\
\text { samples }\end{array}$ \\
\hline$\leq 32$ & $0.268^{*}$ & 1315 & $0.072^{*}$ & 1330 \\
\hline$\leq 45$ & $0.154 *$ & 1770 & $0.065^{*}$ & 1795 \\
\hline$\leq 63$ & $0.128^{*}$ & 2254 & $0.064^{*}$ & 2287 \\
\hline GLOBAL & $0.102 *$ & 3202 & $0.060^{*}$ & 3239 \\
\hline
\end{tabular}

\footnotetext{
* Significance at $\mathrm{P}<5.0 \%$.
} 
Table 8 shows the median values obtained for the several crop years, within each parameter. It could be observed that there was a progressive increase in the kernel hardness from 1990 to 1994 crop year (Figure 4). This fact has been explained by the conscientiousness work, related to technological quality of wheat, started in Brazil in 1989, since when several low quality cultivars were eliminated from planting recomendation and most of new releases were of proved high quality, as reported by Germani \& Carvalho (1996).

Table 8. Median values for the wheat physical characteristics, for all states, by crop year.

\begin{tabular}{|c|c|c|c|c|c|}
\hline \multirow[b]{2}{*}{ Crop year } & \multirow[b]{2}{*}{$\begin{array}{l}\text { Number of } \\
\text { samples }\end{array}$} & \multicolumn{4}{|c|}{ Median } \\
\hline & & $\begin{array}{c}\text { Flour } \\
\text { Extraction } \\
(\%)\end{array}$ & $\begin{array}{l}\text { Test Weight } \\
(\mathrm{kg} / \mathrm{hl})\end{array}$ & $\begin{array}{c}\text { Thousand Kernel } \\
\text { Weight } \\
\text { (gr) }\end{array}$ & $\begin{array}{l}\text { Hardness* } \\
(\mathrm{sec})\end{array}$ \\
\hline 1990 & 850 & $61.54^{\mathrm{D}}$ & $74.2^{\mathrm{D}}$ & $31.97^{\mathrm{D}}$ & $(56.6) \mathrm{SS}^{\mathrm{A}}$ \\
\hline 1991 & 580 & $63.98^{\mathrm{C}}$ & $79.5^{\mathrm{A}}$ & $36.93^{\mathrm{A}}$ & $(52.2) \mathrm{SS}^{\mathrm{B}}$ \\
\hline 1992 & 528 & $64.58^{\mathrm{B}}$ & $78.1^{\mathrm{B}}$ & $36.47^{\mathrm{A}}$ & $(48.3) \mathrm{SS}^{\mathrm{C}}$ \\
\hline 1993 & 614 & $61.34^{\mathrm{E}}$ & $77.5^{\mathrm{C}}$ & $34.16^{\mathrm{B}}$ & $(45.9) \mathrm{SS}^{\mathrm{D}}$ \\
\hline 1994 & 655 & $69.54^{\mathrm{A}}$ & $79.5^{\mathrm{A}}$ & $33.44^{\mathrm{C}}$ & $(40.0) \mathrm{H}^{\mathrm{E}}$ \\
\hline
\end{tabular}

Mean followed by different letter are significantly diferent by the Duncan test at $\mathrm{P}<5.0 \%$.

$* \mathrm{H}=\mathrm{HARD}, \mathrm{SS}=$ semi-soft, $\mathrm{S}=$ soft.

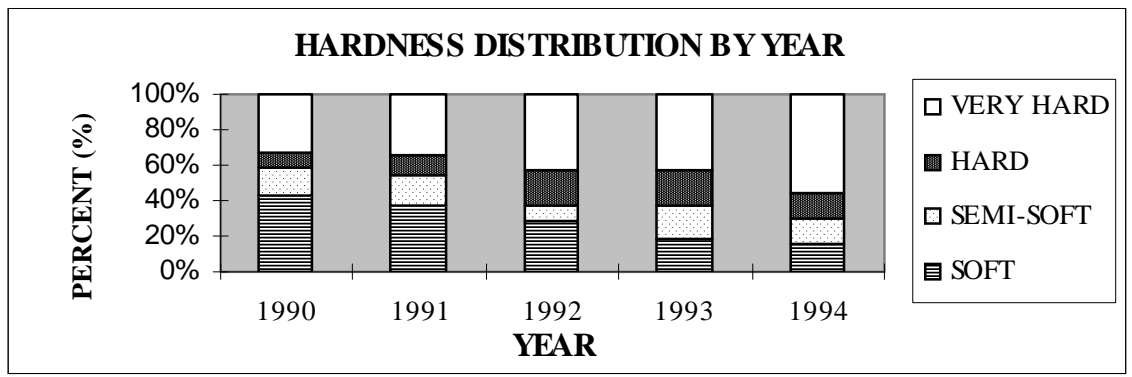

Figure 4. Wheat hardness relative distribution. during the 90 to 94 crop years.

The parameters evaluation (by State) is shown in Table 9. It could be observed that the TW and TKW values were significantly higher for SP and MS/DF/MG/GO States, being the lowest for SC State. In terms of hardness, the wheat from $\mathrm{MS} / \mathrm{DF} / \mathrm{MG} / \mathrm{GO}$ were the hardest, followed by those from SP, PR and RS States, and again being the softest those from SC State. For FE, the best results were also obtained from those sample from SP State, followed by MS/DF/MG/GO, PR and RS States, and those from SC with the lowest FE. This showed that there was a tendency of wheat of high TW, high TKW and high HD resulting in high FE. Therefore, samples from MS/DF/MG/GO States were generally of better quality than those from the other States (SP, PR and RS). Those from SC State showed the poorest quality.
Evaluating the correlation coefficient between FE and the other parameters by crop year and local (Table 10), it could be observed that there was variability among States by crop year, as already indicated by the interaction year/State (Table 7). This variability increased the difficulty of any indication of a tendency. In this segregation high correlation coefficient was obtained, as it was seen for TW in 1990, and for HD in 1992 and 1994 for the MS/DF/MG/GO States. The latter results were endorsed by Table 6 , showing that the higher the hardness, the better the correlation with FE. Table 9 shows that the wheat grown in the MS/DF/MG/GO States was of high hardness. In spite of that the global evaluation by State did not show results as good as the ones obtained in distinct years. 
Table 9. Median values for the wheat physical characteristics, for all years, by State.

\begin{tabular}{lccccc}
\hline & & \multicolumn{4}{c}{ Median } \\
\cline { 3 - 6 } State & $\begin{array}{c}\text { Number of } \\
\text { samples }\end{array}$ & $\begin{array}{c}\text { Flour Extraction } \\
(\%)\end{array}$ & $\begin{array}{c}\text { Test Weight } \\
(\mathrm{kg} / \mathrm{hl})\end{array}$ & $\begin{array}{c}\text { Thousand Kernel } \\
\text { Weight } \\
(\mathrm{gr})\end{array}$ & $\begin{array}{c}\text { Hardness* } \\
(\mathrm{sec})\end{array}$ \\
\hline MS/ DF/ & & & $79.4^{\mathrm{A}}$ & $37.87^{\mathrm{A}}$ & $(33.9) \mathrm{H}^{\mathrm{D}}$ \\
MG/GO & 214 & $65.4^{\mathrm{B}}$ & $77.2^{\mathrm{B}}$ & $33.59^{\mathrm{B}}$ & $(46.7) \mathrm{SS}^{\mathrm{C}}$ \\
PR & 1657 & $64.2^{\mathrm{C}}$ & $76.5^{\mathrm{C}}$ & $29.94^{\mathrm{C}}$ & $(63.0) \mathrm{S}^{\mathrm{A}}$ \\
SC & 132 & $60.7^{\mathrm{E}}$ & $79.0^{\mathrm{A}}$ & $38.57^{\mathrm{A}}$ & $(47.7) \mathrm{SS}^{\mathrm{C}}$ \\
SP & 282 & $68.0^{\mathrm{A}}$ & $77.2^{\mathrm{B}}$ & $34.13^{\mathrm{B}}$ & $(54.9) \mathrm{SS}^{\mathrm{B}}$ \\
RS & 955 & $63.2^{\mathrm{D}}$ & & $75 \%$
\end{tabular}

Median followed by different letter are significantly diferent by the Duncan test, at $\mathrm{P}<5.0 \%$.

$* \mathrm{H}=\mathrm{HARD}, \mathrm{SS}=$ semi-soft, $\mathrm{S}=$ soft.

Table 10. Correlation coefficient between flour extraction (FE) and test weight (TW), thousand kernel weight (TKW) and hardness (HD), by crop year and local.

\begin{tabular}{|c|c|c|c|c|c|c|}
\hline \multirow[b]{2}{*}{ Crop year } & \multicolumn{6}{|c|}{ State } \\
\hline & & S/DF/MG/GO & PR & $\mathrm{RS}$ & SC & SP \\
\hline \multirow{3}{*}{90} & TW & $0.834 *$ & $0.369^{*}$ & $0.245^{*}$ & $0.444^{*}$ & $-0.519^{\mathrm{ns}}$ \\
\hline & TKW & $0.614 *$ & $0.392 *$ & $0.266^{*}$ & $0.485^{*}$ & $0.242^{\mathrm{ns}}$ \\
\hline & HD & $-0.027^{\mathrm{ns}}$ & $-0.095 *$ & $-0.235^{*}$ & $-0.104^{\mathrm{ns}}$ & $-0.297^{\mathrm{ns}}$ \\
\hline \multirow{3}{*}{91} & TW & $0.044^{\text {ns }}$ & $0.009^{\mathrm{ns}}$ & $0.188^{*}$ & N.s.a. & $0.553^{*}$ \\
\hline & TKW & $-0.049^{\mathrm{ns}}$ & $0.085^{\mathrm{ns}}$ & $0.153^{*}$ & N.s.a. & $0.381^{\mathrm{ns}}$ \\
\hline & HD & $-0.676^{*}$ & $-0.604 *$ & $-0.368 *$ & N.s.a. & $-0.479 *$ \\
\hline \multirow{3}{*}{92} & TW & $-0.393^{\mathrm{ns}}$ & $-0.006^{\mathrm{ns}}$ & $-0.312 *$ & N.s.a. & $0.067^{\mathrm{ns}}$ \\
\hline & TKW & $-0.176^{\mathrm{ns}}$ & $0.009^{\mathrm{ns}}$ & $0.218^{\mathrm{ns}}$ & N.s.a. & $0.166^{\mathrm{ns}}$ \\
\hline & HD & $-0.874 *$ & $-0.287 *$ & $-0.219^{\mathrm{ns}}$ & N.s.a. & $-0.553 *$ \\
\hline \multirow{3}{*}{93} & TW & $0.418^{\mathrm{ns}}$ & $0.147^{\mathrm{ns}}$ & $0.044^{\text {ns }}$ & $0.191^{\mathrm{ns}}$ & $0.021^{\mathrm{ns}}$ \\
\hline & TKW & $0.345^{\text {ns }}$ & $0.317 *$ & $0.254 *$ & $0.060^{\mathrm{ns}}$ & $0.050^{\mathrm{ns}}$ \\
\hline & $\mathrm{HD}$ & $-0.448^{\mathrm{ns}}$ & $-0.728 *$ & $-0.123^{\mathrm{ns}}$ & $-0.595^{*}$ & $0.243^{\mathrm{ns}}$ \\
\hline \multirow{3}{*}{94} & TW & $0.142^{\mathrm{ns}}$ & $0.039^{\mathrm{ns}}$ & $0.261^{\mathrm{ns}}$ & N.s.a. & $0.259^{*}$ \\
\hline & TKW & $0.479 *$ & $0.173 *$ & $0.370 *$ & N.s.a. & $0.197^{\mathrm{ns}}$ \\
\hline & HD & $-0.862 *$ & $-0.565^{*}$ & $-0.593^{*}$ & N.s.a. & $-0.584 *$ \\
\hline \multirow{3}{*}{ GLOBAL } & TW & $0.442 *$ & $0.365^{*}$ & $0.137^{*}$ & $0.356^{*}$ & $-0.022^{\mathrm{ns}}$ \\
\hline & TKW & $0.200^{*}$ & $0.204 *$ & $0.187^{*}$ & $0.258^{*}$ & $0.084^{\mathrm{ns}}$ \\
\hline & HD & $-0.324 *$ & $-0.255^{*}$ & $-0.262 *$ & $-0.022^{\mathrm{ns}}$ & $-0.457 *$ \\
\hline
\end{tabular}

* Significance at $\mathrm{P}<5.0 \%$. ${ }^{\text {ns }}$ non significant. N.s.a.= no samples analysed.

\section{RESUMO}

Um extensivo trabalho de determinação de peso do hectolitro grão $(\mathrm{PH})$, peso de mil grãos (PMG) e dureza do grão (DZ), foi realizado durante as safras de 90 a 94, com o objetivo de traçar um perfil do trigo brasileiro e sua implicação na extração de farinha (EXFA). Obteve-se um valor médio de $\mathrm{PH}$ de $78,2 \mathrm{~kg} / \mathrm{hl}$, de PMG de $34,2 \mathrm{~g}$ e uma DZ classificada como semi-dura. Os valores encontrados variaram de acordo com o ano, estado e, dentro do estado, nos diferentes anos. Entre os estados, os melhores resultados foram de amostras provenientes do MS/DF/MG/GO. Correlações entre EXFA e PH, PMG e DZ mostram ser significativas $(\mathrm{P}<5,0 \%)$ mas de baixo valor, não devendo, portanto, estes parâmetros físicos, ser utilizado em relação direta com a extração de farinha mas apenas como indicadores do potencial desta. Segregação dos valores de PH, PMG e DZ, por faixas, não melhoraram as correlações com EXFA. 


\section{REFERENCES}

AACC - American Association Of Cereal Chemists (1983). Approved methods of the American Association of Cereal Chemists, 8. ed. St. Paul.

AOAC - Association Of Official Analytical Chemists (1984). Official methods of analysis of the Association of Official Analytical Chemists, 15. ed. Gaitherburg.

Baker, R.J.; Dyck, P.L. (1975), Relation of several quality characteristics to hardness in two spring wheat crosses. Canadian Journal of Plant Science, 55, 625-627.

El-Shirbeeny, A.; Allam, M. (1987), The thousand seed weight of wheat in relation to the technological properties of wheat. Egyptian Journal of Food Science, 15(1), 83-90.

Germani, R., Benassi, V.T.; Carvalho, J.L.V. de.(1997), Metodologia de avaliação da qualidade tecnológica do grão e da farinha de trigo. Rio de Janeiro: EMBRAPA-CTAA,. 43 p. Course appostille.

Germani, R., Carvalho, J.L.V. (1996), Evolução do perfil da qualidade tecnológica das cultivares de trigo recomendadas para plantio no Brasil entre os anos de 91 e 96. Paper presented at $15^{\text {th }}$ CONGRESSO BRASILEIRO DE CIENCIA E TECNOLOGIA DE ALIMENTOS, Poços de Caldas, MG.
Johnson, J.M.; Harris, C.H. (1995), Test weight of soft red winter wheat related to flour yield and baking quality. Proceedings from Institute of Food Technology Annual Meeting, Chicago: Institute of Food Technology.

Kosmolak, F.G. (1978), Grinding time: a screening test for kernel hardness in wheat. Canadian Journal of Plant Science, 58, 415420.

Kremer, H. (1993), The effect of test weight on milling results. Bulletin of the Association of Operative Millers, 6189-6190.

Schuler, S.F.; Bacon, R.K.; Finney, P.L.; Gbur, E.E. (1995), Characterization of test weight and its relationship to end-use quality of soft red winter wheat. Crop Science, 35(4), 949953.

Shuey, W.C. \& Gilles, K.A. (1972), Milling evaluation of hard red spring wheats. III. Relation of some physical characteristics of wheats to milling results. The Northwestern Miller, 279(2), . 141.

Zeleny, L.( 1978), Criteria of wheat quality. In: Wheat Chemistry and Technology. ed. POMERANZ, Y. American Association of Cereal Chemists, St. Paul:, pp. 19-50.

Received: June 02, 1998 ; Revised: November 16, 1998; Accepted: February 02, 1999. 